\title{
Factors Affecting the Study of Accounting in Nigerian Universities
}

\author{
Odia, J.O. (PhD) \\ Department of Accounting, \\ University of Benin, Benin City, Nigeria \\ odiajames@yahoo.com, 234-8056580011 \\ Ogiedu, K.O. (PhD) \\ Department of Accounting, \\ University of Benin, Benin City, Nigeria \\ koogiedu@yahoo.com, 234-8033600045
}

\section{Doi:10.5901/jesr.2013.v4n3p89}

\begin{abstract}
This paper examines the factors affecting students' career choice of accounting in Nigerian university. The study was conducted using the survey with a sampling population of 300 undergraduates from three universities. It has been discovered that the factors affecting students' career choice of accounting are numerous but they can be group into personal, reference and job factors. The findings indicate that personal and job factors such as students' interest and motivation in the subject, job prospects and high pay, performance in secondary school are the most influencing factors of students' choice of accounting. In particular, male students were found to be more influenced by the reference factors than their female counterparts in the choice of accounting. The paper recommends the need for enlightenment and counseling of the students and their wards about career choice in accounting..
\end{abstract}

Keywords: Accounting, personal factors, job-related factors, choice

\section{Introduction}

In recent years, the declining of accounting students has become a major concern to the accounting profession (Hunt, Falgiani \& Intrieri, 2004). For instance, in the US the decline has been attributed to many factors such as: change in the business environment, decrease in salary level, alternative careers perceived as more attractive to students, misunderstanding and lack of information related to the accounting career (Albrecht \& Sack,2000). In Nigeria, the choice of accounting tends to rank among other professional courses like law, medicine, engineering ,economics etc. Although many researchers have considered the factors affecting students' career choice in accounting, there is dearth of researches in relation to accounting in Nigeria.

Therefore, the purpose of this paper is to examine the factors which influence students' choice of accounting in Nigerian universities and determine whether there are significant differences between male and female accounting students in the choice of accounting. The rest of the paper is organized as follows: Section two reviews the relevant literature on the factors.Section three is the methodology adopted. The data analysis and research findings are documented in Section four and the overall conclusions regarding these results are presented in Section five.

\section{Literature review}

There have been many researches carried out in both developing and developing countries to identify factors influencing student's choice of accounting. Some of the factors considered were subjective factors such are social, cultural, sociological, psychological and personal factors. Others are the objective factors or both categories (Zhang, 2006). Factors frequently cited as determinants of students' career choice are intrinsic values, financial rewards, job market and the cost-benefit. Some of these factors are long term salary possibilities, prestige of the profession, job security and starting salary. It has been found that students consider stereotype about the different careers when making their decisions .Yayla \& Cengiz (2005) find respondents' own choice, family, environment, interesting profession, earnings 
expectations and job opportunities play a significant role in choosing an accounting career. These factors are grouped into personal, reference or and job related factors and considered in subsequent sections.

\subsection{Personal Factors}

Many researchers have identified that the choice of accounting is influenced by the student's interest. For instance, Zhang (2006) finds student's interest in the subject and ability very important in making choice to study accounting. Other factors like quantitative skills and intellectually challenging also influence students' choices (Mladenovic,2000, Zhang, 2006).When students see accounting as interesting and enjoyable, they are more likely to choose it (Saemann \& Calero, 1999., Adam et al 1994., Mauldin et al, 2000). This finding was supported by results of Jackling \& Calero (2006) where intrinsic rewards such as enjoyment of the topics in accounting influence career in accounting. Kaur \& Leen (2006) establish that students' choices of major is influenced by factors such as gender, race, quantitative skills, interest in the subject, expected marketability, performance in major classes, the approachability and teaching reputation of faculty member. Cohen \& Hanno (1993) conduct a survey of 287 students who had either declared or intended to declare themselves as accounting majors and those who had either declared or intended to declare themselves as major in a field other than accounting. The results indicated that non-accounting majors may choose accounting because they believe accounting to be too number-oriented and boring.

\subsection{Reference Group}

Previous studies confirmed that referent group such as: parents, parents' occupation, instructors in high school and friends could influence student's choice of major (Pimpa, 2007, Kim et al, 2002, Paolilo \& Estes 1982, Geiger \& Ogibly 2000, Mauldin et al, 2000, Kim et al,2002). Family plays a critical role in a child's career development (Guerra \& Braungart-Rieker, 1999). High school teachers and college instructors play a significant role in students' final choice of business major. However, Hardin et al (2000) find high school educators to have a relatively low opinion of accounting as a career option for high school students. Similarly, parents and instructors had a strong influence on student's choice of majors (Inman et al, 1989, Mauldin et al, 2000., Tan \& Laswad, 2006).

Mauldin et al (2000) investigate the choices of accounting major and find the largest percentage of students who chose accounting as their major during the first accounting course in college (41\%) followed by selection during high school (34\%). They also find twelve factors that influence the student's decisions to include: career opportunities, interest in the subject, instructors, money, parents, enjoyments, previous experience, life style opportunity because of the career, challenge, prestige, usefulness in rating a business and other students. Among referents, the instructor was found to be the most influential factor.

\subsection{Job Related Factors}

Job attributes are the most important factors that influence the choice of career among undergraduates. The job related include: the job itself, compensation or security and the company or work environment (Moy \& Lee, 2002, Teo \& Poon (1994).The influencing factors are job satisfaction (Paolilo \& Estes,1982), higher earnings, prestige and career advancement (Kim,et al, 2002). Lowe \& Simons (1997) study the relative importance of 13 factors influencing the choice of business major. They find that the most important criteria influencing the choice of major business students are: future earnings, career options, initial earnings and ability/aptitude. Moreover, they find distinguishable differences among majors. For example, accounting students were influenced by external factors such as: long term earnings, initial earnings and career options whereas marketing majors highlighted interesting subject matter and management majors rated self employment opportunities highly. These findings support the results that students' choice of business major are influenced by earnings, prestige and career advancement (Tan \& Laswad, 2006, Maudlin et al 2000, Felton et al, 1994). Noland et al (2003) find the factors influencing major selection by accounting and information systems majors are longterm salary possibilities, prestige of the profession, job security, and starting salary; the influence of a professor, family members and difficulty of the subject matter are rated much lower.

Kim et al (2002) conducted a study on business majors (accounting, finance, general business, management, marketing, management information system and double major). They discovered that the top five reasons for choosing a major were: interest in a career, good job opportunities, "good fit" with respondents' abilities, a desire to run a business some day and projected earnings in the related career. The least selected reasons for choosing a major were the 
reputation of the major at the university, the perceived quality of instruction, the parents' influence, the amount and type of promotional information and the influence of friends.

\subsection{Perception of Accounting}

Accounting education has been the subject of considerable debates since 1980s. Prior researches document that introductory accounting students have negative perception of accounting. Accounting is attractive to the students in terms of profession but the "negative views regarding the nature and role of accounting persist (Fisher \& Murphy, 1995:58). Society's perception of the legitimacy of the accounting profession and its members is grounded in the verbal and visual images of accountants that are projected not only by accountants themselves but also by the media. How accountants are portrayed in media have a significant impact on the accounting profession. Typically, accountants have been referred to as number crunchers, focusing on numerical accuracy, routine recording and calculation methods.

Abrecht \& Sack (2000), Cory (1992), Garner \& Dombrowski (1997) attribute the negative perception to misinformation or lack of information about accounting and the duties performed by accountants. To date, efforts by professional accounting bodies and firms to change the negative and inaccurate perception of accountancy and accountants have yielded limited success (Jackling \& Calero, 2006). Byrne \& Willis (2005) maintain that the public view of accountants is generally negative and that this perception might discourage potential students from studying the subject. Similarly, Cohen \& Hanno (1993) find that the perception of accounting as boring and excessively numberoriented might lead student to choose other majors than accounting. Furthermore, the traditional view of accounting as involving precision and order has been found to drive creative people away from the profession.

In addition, many bright young people are seeking careers in professional fields other than accounting as a result of the poor image of the accounting profession (Saemann \& Crooker 1999, Cohen \& Hanno,1993). The personal image of accountants and how they market themselves are more important than the price, product and "Smart'.Anyone whose success depends upon or requires the cooperation of another individual or group needs a positive personal image. Unfortunately, high-quality students hardly ever perceive accountants as they perceive themselves. People regard accountants as boring, middle- aged men sitting in a back office with a calculator and a stack of flies. As a consequence, the accounting profession does not always attract high quality students. Whether a person chooses to pursue an accounting career may be determined by the image of accountants in the media. Byrne \& Willis (2005) find that perceptions of accounting are influenced by factual media. Mathus \& Fowler (2009) find that the portrayal of accountants in the media could be recalled by the sampling group. Tan \& Laswad (2009) in an extension of their 2006 study survey university students at the beginning and end of their degree. The comparisons between accounting and non accounting students reveal that those who intended to major in accounting generally hold positive attitudes towards the accounting profession. Tan \& Laswad (2009) found that a higher proportion of accounting students decide on their major prior to university study. Therefore they recommended that the accounting profession should promote the positive aspects of accounting career not only to pre-university students but also to the public as this strategy would enhance the public profile of members of the profession.

\subsection{Status of accounting compared with other professions}

Students are more likely to aspire to a career that is held in high esteem by society. In the Byrne \& Willis (2005) study, accounting students ranked accounting ranked $5^{\text {th }}$ and non-accounting students ranked it $7^{\text {th }}$ among ten professional courses. Irish high schools ranked accountants behind doctors, lawyers, dentists and architects as professionals. In the United States, the Gallun organization (1991) reported that both high school and university students rated the accounting profession last among six professions of law, medicine, teaching, engineering, financial planning and accounting. In a New Zealand study, the accounting profession was ranked lower in social status compared to the profession of law, medicine and engineering by high school teachers. This was also the view of high school teachers in the United States (Hardin et al, 2000) and Japan (Sagahara et al, 2006)

\section{Methodology}

The population of interest comprised all accounting students in three (3) universities: University of Benin (UNIBEN), Igbinedion University Okada (IUO) and Ambrose Alli University (AAU). The sample size was made up of three hundred (300) full and part-time accounting students from these universities. The total number include: two hundred (200) 
accounting students from UNIBEN, fifty (50) from IUO and fifty (50) students from AAU. The data for this study was mainly from the administration of questionnaire. A total of 300 questionnaires were administered and retrieved from the respondents representing a response rate of 100\%. The likert scale type close ended questions was used. The data was analysis using percentage analysis, independent t-test and regression analysis.The t-test was used to find out if there was significant difference between male and female accounting students in the choice of accounting. The descriptive statistics of the respondents is shown in table 1 below.

Table 1. Descriptive statistics

\begin{tabular}{|c|c|c|}
\hline & No of Respondents & Percentage (\%) \\
\hline Sex & & \\
\hline Male & 170 & $56.67 \%$ \\
\hline Female & 130 & $43.33 \%$ \\
\hline Age & & \\
\hline $15-20 y r s$ & 145 & $48.33 \%$ \\
\hline 21-25yrs & 113 & $37.57 \%$ \\
\hline 26-30yrs & 30 & $10 \%$ \\
\hline Above 30yrs & 8 & $2.6 \%$ \\
\hline Marital Status & & \\
\hline Single & 282 & $94 \%$ \\
\hline Married & 15 & $5 \%$ \\
\hline Divorced & 0 & $0 \%$ \\
\hline Widow/Widower & 1 & $0.33 \%$ \\
\hline Religion & & \\
\hline Christianity & 276 & $92 \%$ \\
\hline Islam & 16 & $5.33 \%$ \\
\hline Others & 0 & $0 \%$ \\
\hline Levels & & \\
\hline 100 & 48 & $16 \%$ \\
\hline 200 & 72 & $24 \%$ \\
\hline 300 & 71 & $23.67 \%$ \\
\hline 400 & 80 & $26.67 \%$ \\
\hline 500 & 6 & $2 \%$ \\
\hline 700 & 6 & $2 \%$ \\
\hline 800 & 3 & $6.67 \%$ \\
\hline Certificate In View & & \\
\hline B.Sc & 291 & $97 \%$ \\
\hline M.Sc & 9 & $3 \%$ \\
\hline Ph.D & 0 & $0 \%$ \\
\hline Programme & & \\
\hline Full Time & 266 & $88.6 \%$ \\
\hline Part Time & 32 & $10.6 \%$ \\
\hline Professional Qualifications & & \\
\hline ACA & 59 & $19.67 \%$ \\
\hline ACCA & 0 & $0 \%$ \\
\hline Universities & & \\
\hline Benin & 200 & $66.67 \%$ \\
\hline Igbinedion & 50 & $16.67 \%$ \\
\hline Ambrose Alli & 50 & $16.67 \%$ \\
\hline
\end{tabular}

Source: Field Survey (2012)

\section{Analyses of questionnaire responses}

Table 2 shows that personal factors have a very high influence on students' choice of accounting as shown by the percentage of total agreement of over $85 \%$ for the items. In terms of percentage ranking, students' likeness of accounting $\left(1^{\text {st }}\right)$, accounting is interesting $\left(2^{\text {nd }}\right)$, thought of better grade and performance $\left(3^{\text {rd }}\right)$, love for calculations $\left(4^{\text {th }}\right)$, prestige as 
an accountant $\left(5^{\text {th }}\right)$ are among the most influencing personal factors whereas the least influencing personal factors are the thinking by the students that 'learning accounting is challenging', and 'I like to answer questions in figures'. The female accounting students had a greater mean scores than the male students on accounting is interesting, possession of quantitative skills to cope with accounting calculations and class works, answer questions in figures and maintain high GPA.

Table 2. Personal factors influencing students' choice of accounting

\begin{tabular}{|c|c|c|c|c|c|c|c|c|c|c|c|c|}
\hline \multirow{3}{*}{ S/N } & \multirow{3}{*}{ Questions } & \multicolumn{8}{|c|}{ Responses } & \multirow{3}{*}{$\left|\begin{array}{c}\text { Total } \\
\text { Agree } \%\end{array}\right|$} & \multirow{3}{*}{ Rank } & \\
\hline & & \multicolumn{2}{|c|}{ SA } & \multicolumn{2}{|c|}{ A } & \multicolumn{2}{|r|}{ D } & \multicolumn{2}{|c|}{ SD } & & & $\begin{array}{c}\text { Independen } \\
\mathrm{t} \\
\mathrm{t} \text {-test }\end{array}$ \\
\hline & & No & $\%$ & No & $\%$ & No & $\%$ & No & $\%$ & & & \\
\hline 1 & I like accounting & 188 & 62.67 & 102 & 34 & 8 & 2.67 & 2 & 0.67 & $96.67 \%$ & (1) & $1.142 \mathrm{a}$ \\
\hline 2 & Accounting is interesting & 120 & 40 & 164 & 54.67 & 13 & 4.33 & 2 & 0.67 & $94.67 \%$ & (2) & $0.110 \mathrm{~b}$ \\
\hline 3 & I would enjoy being an accountant & 150 & 50 & 126 & 42 & 16 & 5.33 & 5 & 1.67 & $92 \%$ & (6) & $0.997 \mathrm{a}$ \\
\hline 4 & I am willing to learn accounting subject & 134 & 44.67 & 145 & 48.33 & 16 & 5.33 & 4 & 1.33 & $93 \%$ & (4) & $0.659 \mathrm{a}$ \\
\hline 5 & $\begin{array}{l}\text { I am willing to spend a lot of time } \\
\text { studying accounting }\end{array}$ & 134 & 44.67 & 128 & 42.67 & 29 & 9.67 & 7 & 2.33 & $87.34 \%$ & (9) & 0.864 a \\
\hline 6 & I can do better in calculation & 137 & 45.67 & 140 & 46.67 & 13 & 4.33 & 8 & 2.67 & $92.34 \%$ & (5) & $0.786 \mathrm{~b}$ \\
\hline 7 & I like to answer questions in figures & 126 & 42 & 136 & 45.33 & 23 & 7.67 & 10 & 3.33 & $87.33 \%$ & $(10)$ & $0.373 \mathrm{~b}$ \\
\hline 8 & $\begin{array}{l}\text { Accounting is a course with lots of } \\
\text { class work }\end{array}$ & 129 & 43 & 135 & 45 & 26 & 8.67 & 5 & 1.67 & $88 \%$ & (8) & $0.059^{*} \mathrm{~b}$ \\
\hline 9 & $\begin{array}{l}\text { Learning accounting is very } \\
\text { challenging }\end{array}$ & 125 & 41.67 & 132 & 44 & 31 & 10.33 & 8 & 2.67 & $85.67 \%$ & (11) & $0.392 \mathrm{~b}$ \\
\hline 10 & $\begin{array}{l}\text { I can maintain high grade point } \\
\text { average }\end{array}$ & 143 & 47.67 & 143 & 47.67 & 7 & 2.33 & 5 & 1.67 & 94.34\% & (3) & $0.932 \mathrm{~b}$ \\
\hline 11 & $\begin{array}{l}\text { My motivations made me choose } \\
\text { accounting course }\end{array}$ & 166 & 55.33 & 103 & 34.33 & 21 & 7 & 7 & 23.33 & 89.66\% & (7) & $1.396 \mathrm{a}$ \\
\hline
\end{tabular}

Source: Field Survey (2012) * significant at $10 \%$ level $a=$ mean score of male student greater than the female, $b=$ mean score of female student greater than the male

Table 3 shows the responses of the reference factors on students' choice of accounting. It seems that there is not much influence of reference factors such as: counselors (52.34\%), parents (51.33\%), friends (50\%), teachers at secondary school (49\%),parents' occupation (43\%) and other students (37.6\%).Nevertheless, counsellors (formal and informal), parents and friends tend to have more influence than parents' occupation and fellow students. Again, the agreement on students' performance on secondary subjects shows the pre-eminence of personal factors in students' choice of accounting. This shows that if students perform very well in the secondary school subjects, they are likely to choose accounting when applying to the universities.

Table 3. Reference factors and students choice of accounting

\begin{tabular}{|c|c|c|c|c|c|c|c|c|c|c|c|c|}
\hline \multirow{3}{*}{$S / N$} & \multirow{3}{*}{ Questions } & \multicolumn{8}{|c|}{ Responses } & \multirow{3}{*}{$\begin{array}{c}\text { Total } \\
\text { Agreed } \\
\% \\
\end{array}$} & \multirow{3}{*}{ Rank } & \multirow{3}{*}{$\begin{array}{c}\text { Independen } \\
t \\
\text { t-test } \\
\end{array}$} \\
\hline & & \multicolumn{2}{|c|}{ SA } & \multicolumn{2}{|c|}{ A } & \multicolumn{2}{|c|}{ D } & \multicolumn{2}{|c|}{ SD } & & & \\
\hline & & No & $\%$ & No & $\%$ & No & $\%$ & No & $\%$ & & & \\
\hline 1 & $\begin{array}{l}\text { My parents wants me to choose } \\
\text { accounting course }\end{array}$ & 61 & 20.33 & 93 & 31 & 80 & 26.67 & 65 & 21.67 & $51.33 \%$ & (3) & $2.272^{\star \star} a$ \\
\hline 2 & $\begin{array}{l}\text { My friend think i should chose } \\
\text { accounting course }\end{array}$ & 58 & 19.33 & 10.7 & 35.67 & 63 & 21 & 71 & 23.67 & $50 \%$ & (4) & $2.009^{\star \star} \mathrm{a}$ \\
\hline 3 & $\begin{array}{l}\text { Other students recommend } \\
\text { accounting to me }\end{array}$ & 44 & 4.67 & 99 & 33 & 78 & 26 & 76 & 25.33 & $37.67 \%$ & (7) & $0.856 \quad a$ \\
\hline 4 & $\begin{array}{l}\text { My teacher think i should take } \\
\text { accounting course }\end{array}$ & 68 & 22.67 & 85 & 28.33 & 64 & 21.33 & 81 & 27 & $49 \%$ & (5) & $1.165 \mathrm{a}$ \\
\hline
\end{tabular}




\begin{tabular}{|c|l|c|c|c|c|c|c|c|c|c|c|c|}
\hline 5 & $\begin{array}{l}\text { My counselor(s) at school } \\
\text { recommend accounting to me }\end{array}$ & 47 & 15.67 & 110 & 36.67 & 87 & 29 & 54 & 18 & $52.34 \%$ & (2) & $1.503 \quad$ a \\
\hline 6 & $\begin{array}{l}\text { My performance in secondary } \\
\text { school subject make me choose } \\
\text { accounting course }\end{array}$ & 196 & 63.33 & 92 & 30.67 & 6 & 2 & 7 & 2.33 & $94 \%$ & (1) & $1.921 \quad \mathrm{~b}$ \\
\hline 7 & $\begin{array}{l}\text { My parent's occupation } \\
\text { encouraged me to choose } \\
\text { accounting }\end{array}$ & 55 & 18.33 & 74 & 24.67 & 84 & 28 & 86 & 28.67 & $43 \%$ & $(6)$ & $2.172^{\star \star} \mathrm{a}$ \\
\hline
\end{tabular}

Source: Field survey (2012), ${ }^{*}$ Significant at $5 \%$ level $\quad a=$ mean score of male student greater than the female, $b=$ mean score of female student greater than the male

In table 2, the mean scores of the male accounting student for all the reference factors is greater than the female accounting students except performance in secondary school subjects indicate that the male students were more influenced than their female counterparts by these factors such as parents, parent's occupation, friends, teachers fellow students and counsellors. Moreover, there are significant differences between male and female student in respect of the influencing factors as parents, friends and parent's occupation.

Table 4. Job related factors

\begin{tabular}{|c|c|c|c|c|c|c|c|c|c|c|c|c|}
\hline \multirow{3}{*}{$S / N$} & \multirow{3}{*}{ Questions } & \multicolumn{8}{|c|}{ Responses } & \multirow{3}{*}{$\begin{array}{c}\text { Total } \\
\text { Agree } \%\end{array}$} & \multirow{3}{*}{ Rank } & \multirow{3}{*}{$\begin{array}{c}\text { Independ } \\
\text { ent } \\
\text { t-test }\end{array}$} \\
\hline & & \multicolumn{2}{|c|}{$S A$} & \multicolumn{2}{|c|}{$A$} & \multicolumn{2}{|r|}{$D$} & \multicolumn{2}{|c|}{$S D$} & & & \\
\hline & & No & $\%$ & No & $\%$ & No & $\%$ & No & $\%$ & & & \\
\hline 1. & $\begin{array}{l}\text { I choose accounting course because } \\
\text { there will be job available for me } \\
\text { when I graduate }\end{array}$ & 120 & 40 & 150 & 50 & 24 & 8 & 6 & 1.67 & $90 \%$ & (3) & $0.715 b$ \\
\hline 2. & $\begin{array}{l}\text { I choose accounting course because } \\
\text { there will always be a great job } \\
\text { market demand for people like me }\end{array}$ & 122 & 40.67 & 148 & 49.33 & 20 & 6.67 & 6 & 2 & $90 \%$ & (3) & $0.804 \mathrm{~b}$ \\
\hline 3. & $\begin{array}{l}\text { I can get a high paying job if I } \\
\text { graduate with accounting degree }\end{array}$ & 192 & 64 & 96 & 32 & 10 & 3.3 & 2 & 0.67 & $96 \%$ & (2) & $1.228 \mathrm{a}$ \\
\hline 4. & $\begin{array}{l}\text { My starting salary will be satisfying if } \\
\text { I graduate with accounting degree }\end{array}$ & 97 & 32.33 & 152 & 50.67 & 40 & 13.33 & 4 & 1.33 & $83 \%$ & (8) & $0.151 \mathrm{a}$ \\
\hline 5. & Accountants are boring people & 40 & 13.33 & 63 & 21 & 89 & 29.67 & 101 & 33.67 & $34.33 \%$ & (9) & $1.396 \mathrm{a}$ \\
\hline 6 & $\begin{array}{l}\text { Being an accountant has a lot of } \\
\text { prestige }\end{array}$ & 134 & 44.66 & 135 & 45 & 18 & 6 & 5 & 1.67 & $89.66 \%$ & (5) & $1.351 \mathrm{~b}$ \\
\hline 7 & $\begin{array}{l}\text { The accounting profession is well } \\
\text { respected }\end{array}$ & 134 & 44.66 & 135 & 45 & 18 & 6 & 5 & 1.67 & $.66 \%$ & (5) & $0.063 \mathrm{a}$ \\
\hline 8 & $\begin{array}{l}\text { Accounting is a professional in par } \\
\text { with medicine and law }\end{array}$ & 113 & 37.67 & 142 & 47.33 & 33 & 11 & 11 & 3.67 & $80 \%$ & (9) & $0.176 \mathrm{~b}$ \\
\hline 9. & $\begin{array}{l}\text { Accounting is a field with broad } \\
\text { exposure to business }\end{array}$ & 144 & 48 & 131 & 48.67 & 13 & 4.33 & 2 & 0.67 & $96.67 \%$ & (1) & $0.690 \mathrm{~b}$ \\
\hline
\end{tabular}

Source: Field survey (2012), $a=$ mean score of male student greater than the female, $b=$ mean score of female student greater than the male

In table 4, it was found that the respondents believed that the major job-related factors influencing the choice of accounting are: broad exposure by accounting to business, prospects of high paying jobs, high demand for accounting graduates in the labour market, good starting salary for accounting graduates, prestige of the profession. The respondents disagree that accountants are boring people. The t-test shows there are no significant differences between male and female accounting students as regards job-related factors in the choice of accounting 


\section{Conclusion}

It was discovered that personal factors and job-related factors such as student interest, prospects of high paying job and performance in secondary school had stronger influence on the choice of accounting by universities' undergraduate in Nigeria. Our findings confirm with the studies like: Felton et al (1994), Mauldin et al (2000), Tan \& Laswad (2006\& 2009), Intan Shairah et al (2009) and Sugahara et al (2009) that the major influence affecting choice of accounting by students of accounting was based on personal factors or intrinsic values. Our study also reports that the job -related factors are also important factor in students. Although the referent factors were found to be less important compared with the personal and job-related factors, the male accounting students were discovered to be more influenced by the referent factors than the female accounting students.

\section{Recommendations}

Having established the various factors such as student's interest, performance in secondary school and high paying job prospects affect students' choice of accounting, the following recommendations are put forward to attract the brightest and best brains to the study of accounting: First, a good emphasis of accounting should be promoted at the pre-university level if students are to be attracted to choose accounting as a course of study. Students should be exposed to the success stories of various personalities who study accounting and the career profile as well as their contributions to the society, industrial world, national economy and the world at large. The increasingly critical roles of accountants due to their dexterity, versatility and complement with other disciplines in today's world must also be emphasized with change the negative perception and arouse students' interest due to the misinformation and misunderstanding of the personality, functions and career prospects of accountants and the profession. There should be counselling unit to help the students in the choice of their courses.

Second, the accounting profession must continue to emphasize and promote integrity, ethical code of conduct by its members and stem the tides of corporate scandals which have led to the negative image and perception of the profession. Apart from severe sanctions for erring members and practitioners at the private and public sectors, the profession must engage in publicity and enlightenment programme to educate the public on its roles and relevance. The profession and auditing firms should encourage the study of accounting through training the trainers in secondary schools and universities, and support researches in accounting.

There is also the need to employ good, seasoned and qualified accounting teachers and lecturers who will be able to match the theories with the practical realities in the corporate world. The provision of a robust accounting programme and curriculum which is broad-based in training and practically-oriented is more likely to create more interest to students and their wards.

\section{References}

Adams, S.J., Pryor, L.J. \& Adams, S.L. (1994).Attraction and retention of high-aptitude students in accounting: An exploratory longitudinal study. Issues in Accounting Education, 9(1),45-58.

Albrecht, W. S. \& Sack, R. J (2000). Accounting education: Charting the course through a perilous future. Accounting Education Series, No.16, Sarasota Florida: American Accounting Association.

Adrian, Frances (2000). The portrayal of accountants in high profile New Zealand newspaper. Retrieved from http//www.manukau.ac.nz Ifrance.26/06/2012.

Ali U., Ali H. \& Cemil K. (2006).Factors affecting students' career choice in accounting: The case of Turkish University. Retrieved from http//www.journals.cluteonline.com 26/06/2012.

Byrne M. \& Willis P. (2005). Irish secondary students' perception of the work of an accountant and the accounting profession. Accounting Education, 14, 367-381.

Cohen, J \& Hanno. D. M. (1993). An analysis of the underlying constructs affecting the choice of accounting as a major. Issues in Accounting Education, 8(2), 219-238.

Felton, S., Buhr, N \& Northey, M. (1994).Factors influencing the business student's choice of a career in chartered accountancy. Issues in Accounting Education, 9, 131-141.

Fisher, R. \& Murphy, V. (1995) A pariah profession? Some student perceptions and their effect on the decision to major in accounting. Studies in Higher Education,20(1), 45-58.

Garner, R.M. \& Dombrowski, R.F. (1997).Recruiting the best and brightest: The role of university accounting programs and state CPA societies. Issues in Accounting Education 12(2),299. 
Geiger, M.A. \& Ogilby, S.M. (2000).The first course in accounting: student's perceptions and their effect on the decision to major in accounting. Journal of Accounting Education,18, 63-78.

Guerra, A. L. \& Braungart-Rieker, J. M., (1999). Predicting career decision in college students: The roles of identity formation and parental relationship factors. The Career Development Quarterly, 47.

Gul, F. A., Andrew, B. H., Leong, S. C \& Ismail, Z. (1989). Factors influencing choice of discipline of study-accountancy, engineering, law and medicine. Accounting and Finance (November), 93-101.

Hew F, Kamala Y. \& Yeo, E. (2007). Underlying factors of career choice. Retrieved from www.ichl.intimal.edu.my/ictl2007.26/06/2012

Hardin, J.R., O'Bryan, D \& Quirin, J.J. (2000). Accounting versus engineering, law, and medicine: Perceptions of influential high school teachers. Advances in Accounting, 17, 205-220.

Hunt, S. C., Falgiani, A. A \& Intrieri, R. C. (2004).The nature and origins of students' perceptions of accountants. Journal of Education for Business, 79, 142-148

Intan Sharrah \& Che Din (2009).Factors influencing Polimas students in choosing diploma accounting course as their major. Retrieved from www.etd.uum.edu./my1803/1/ Inan. Sharia sarah 26/06/2012.

Jackling, B. \& Calero, C. (2006).Influences on undergraduate students' intentions to become qualified accountants: evidence from Australia, Accounting Education:An international Journal, 15(4), 419-437.

Kochung E. \& Migunde Q (1997).Factors influencing students career choices among secondary school students in Kisumu municipality, Kenya. www.jeteraps.scholar 26/06/2012.

Lowe, D. \& Simons, K. (1997) Factors influencing choice of business major - some additional evidence: A research note. Accounting Education: An International Journal, 6(1), 39-45.

Mauldin, S., Crain, J.L. \& Mounce, P.H. (2000). The accounting principles instructor's influence on student's decision to major in accounting. Journal of Education for Business, 75(3), 142-148.

Malthus, S. \& Fowler, C. (2008).Perceptions of accounting: A qualitative New Zealand study. Pacific Accounting Review, 21, 26-47.

Malthus, S. \& Fowler,C. (2009). Perceptions of accounting as a career: A qualitative New Zealand study. Presented at the 2008 AFAANZ conference, Sydney.

Mladenovic, R. (2000) An investigation into the ways of challenging introductory accounting students' attitudes towards accounting as a profession. Accounting Education: An International Journal, 12(2),113-133.

Mohd Raime, Rokiah I. \& Mond Ateo (2003). Factors Influencing accounting undergraduate career choice in chartered accountancy. Retrieved from www.pst.uum.edu.

Moy, J.W. \& Lee, S.M. (2002). The career choice of business graduates: SMEs or MNCs? Career Development International, 7(7/6), 334-347.

Myburgh J.E. (2000). An empirical analysis of career choice factors that influence first year accounting students at the University of Victoria: A cross racial study. Retrieved from http://www.onoeraldinsight.com/nnals.htm. 26/06/2012

Paolillo, J. \& Estes, R. (1982).An empirical analysis of career choice factors among accountants, attorneys, engineers and physicians. The Accounting Review,62(30)785-793.

Pimpa, N. (2007). The influence of normative referents on Thai students' choice of international education [online] Monash Centre for Research in International Education. http://www.aare.edu.au/01pap/pim01016.htm

Saemann, G. P \& Crooker, K.J. (1999). Student perceptions of the profession and its effect on decisions to major in accounting. Journal of Accounting Education, 17, 1-22

Sugahara, S., Hiramatsu,K \& Boland,G (2007). Do negative perceptions of certified public accountants drive students' career aspirations? A Japanese Study

Sugahara, S., Kurihara O. \& Boland. G. (2006) Japanese secondary school teachers' perceptions of the accounting profession, Accounting Education: An International Journal,15(4), 405-418.

Sugahara, S. \& Boland G. (2009). The accounting profession as a career choice for tertiary business student in Japan-Factor analysis. Accounting Education,18(8),255-270.

Tan, L.M. \& Laswad, F. (2006). Students' beliefs, attitudes and intentions to major in accounting. Accounting Education:An International Journal, 15(2),167-187.

Tan, L.M. \& Laswad,F.(2009) Understanding students' choice of academic majors: A longitudinal analysis. Accounting Education: An International Journal, 18 (3),233-253.

Taylor Research and Consulting Group, Inc. (2000, July). AICPA student and academic research study. Final quantitative report

Teo, H.A. \& Poon, J.T.F.(1994). Career choice of undergraduates and SMEs in Singapore. The International Journal of Career Management, 6(3),20-26.

Thomas S. William. J.G \& Kent A.W (2006). Factors influencing major selection by college of business students. Retrieved from www.racis.org/iis/2006Cramption. Walstio 26/06/2012

Yayla, H.E \& ve Cengiz, E. (2005). Muhasebe Mesleğinin Tercih Edilmesinde Etkili Olan Faktörlerin Belirlenmesine Yönelik Bir Alan Çalışması: Karadeniz Teknik Üniversitesi Örneği. Muhasebe ve Denetime Bakış, Eylül, pp. 147-168. 